American Journal of Biochemistry and Biotechnology 2 (3): 89-96, 2006

ISSN 1553-3468

(c) 2006 Science Publications

\title{
Reduction of Microbial Population in Cheese Whey by UV in a Single and Series Conventional Reactors
}

\author{
A.E. Ghaly and J.P. Singh \\ Department of Process Engineering and Applied Science, Dalhousie University \\ Halifax, Nova Scotia, Canada B3J 2X4, P.O. Box 1000
}

\begin{abstract}
In this study, the effectiveness of two conventional UV reactors in series for the online sterilization of cheese whey was compared to that of a single conventional reactor. The single reactor and the two reactor series were tested at eleven flow rates $(5,10,15,20,25,30,35,40,50,60$ and 70 $\left.\mathrm{mL} \mathrm{min}^{-1}\right)$ and five flow rates, $\left(35,40,50,60,70 \mathrm{~mL} \mathrm{~min}^{-1}\right)$, respectively. $100 \%$ destruction efficiency could not be achieved in the single reactor. When two reactors were connected in series, the destruction efficiency reached $100 \%$ at the flow rate of $35 \mathrm{~mL} \mathrm{~min}^{-1}$ and lasted for $25 \mathrm{~min}$. The temperature of the effluent decreased with the increase in flow rate in both systems. The rate of microbial destruction in the single reactor and the two reactor series was described by an exponential equation. The maximum effluent temperatures in the single reactor and the two reactor series were 45.8 and $36.0^{\circ} \mathrm{C}$, respectively. The flow in both reactors was laminar $\left(\mathrm{R}_{\mathrm{e}}=1.39\right.$ at $5 \mathrm{~mL} \mathrm{~min}^{-1}$ and $\mathrm{R}_{\mathrm{e}}=$ 20.10 at $70 \mathrm{~mL} \mathrm{~min}^{-1}$ ). Visual observation revealed less fouling on the UV lamps of two reactor series than the single reactor. A different design in which there is no contact between the liquid and the UV lamp should be investigated. The quartz sleeve could also be replaced with fluropolymer coiled tube around the UV lamp. The smooth surface of the fluropolymer would reduce scaling and extend the effective operating time.
\end{abstract}

Key words: Sterilization, cheese whey, ultraviolet radiation, conventional reactor, fouling

\section{INTRODUCTION}

Cheese whey is a by-product from cheese or casein manufacture that contains lactose, protein, salts, lactic acid and traces of vitamins ${ }^{[1-3]}$. The total annual world production of cheese whey is about 139.6 million metric tons of which 35.2 and 3.1 million metric tons are produced annually in the United States and Canada, respectively ${ }^{[4]}$. The actual market trends point to a gradual increase in cheese production that generates large amounts of liquid whey per year ${ }^{[3,5,6]}$.

If discarded untreated into the waterways, cheese whey can cause serious environmental problems due to its high biological oxygen demand $\left(\sim 40000 \mathrm{mg} \mathrm{L}^{-1}\right)$ and chemical oxygen demand $\left(\sim 60000 \mathrm{mg} \mathrm{L}^{-1}\right)$ as reported by Hall and Adams ${ }^{[7]}$ and $\mathrm{Siso}^{[6]}$. Although cheese whey contains valuable fertilizer components such as nitrogen, phosphorus and potassium, application on land endanger the physical and chemical structure of the soil thus decreasing the crop yield ${ }^{[8]}$.

Several value added products have been produced from cheese whey using various fermentation processes in order to minimize the problems associated with its disposal and improve the economics of dairy and food processing industry. These include: ethano ${ }^{[9]}$, single cell protein ${ }^{[10,11]}$, organic acids ${ }^{[2,13]}$, biopolymers ${ }^{[14]}$, icers and anti-icers ${ }^{[15,16]}$ and biodegradable plastics ${ }^{[16]}$. However, to produce a pure fermentation product, a culture of a certain organism (or organisms) must be grown in a sterilized nutrient medium.

Sterilization of cheese whey using thermal processes is time consuming and cause denaturing of proteins ${ }^{[9]}$. In order to save time and reduce cost while ensuring complete destruction of micro-organisms several authors suggested sterilization of cheese whey using UV radiation as an attractive alternative to pasteurization ${ }^{[17,18]}$. However, fouling of UV reactors has been reported by several authors ${ }^{[17-20]}$.

In an effort to minimize fouling and increase the destruction of microorganisms during cheese whey sterilization using UV reactors, Mahmoud and Ghaly ${ }^{[17]}$ decreased the gap size (flow thickness) in order to reduce the heat generated by a low pressure UV lamp. Singh and Ghaly ${ }^{[18]}$ suggested a proper combination of flow rate and reactor design to increase the efficiency of the UV reactors. Forney and Pierson ${ }^{[21]}$ suggested the use of two concentric cylinders surrounded by UV lamps, to provide sufficient microbial exposure, to UV radiation. Beltran and Canovas ${ }^{[22]}$ suggested the use of more than one reactor to increase the disinfection effectiveness.

The aim of this study was to evaluate the effectiveness of conventional UV reactor series for continuous sterilization of cheese whey. The specific objectives were: (a) to compare the destruction efficiencies of a single conventional UV reactor and a

Corresponding Author: A.E. Ghaly, Department of Process Engineering and Applied Science, Dalhousie University, Halifax, Nova Scotia, Canada B3J 2X4, P.O. Box 1000, Tel: 902494-6014, Fax: 902423-2423 
two conventional reactor series at various flow rates (residence times) and (c) to investigate the susceptibility of these reactors to fouling during the online sterilization process.

\section{MATERIALS AND METHODS}

The experimental set up (Fig. 1) consisted of UV reactors, cheese whey feeding and effluent removal system and a data logger.

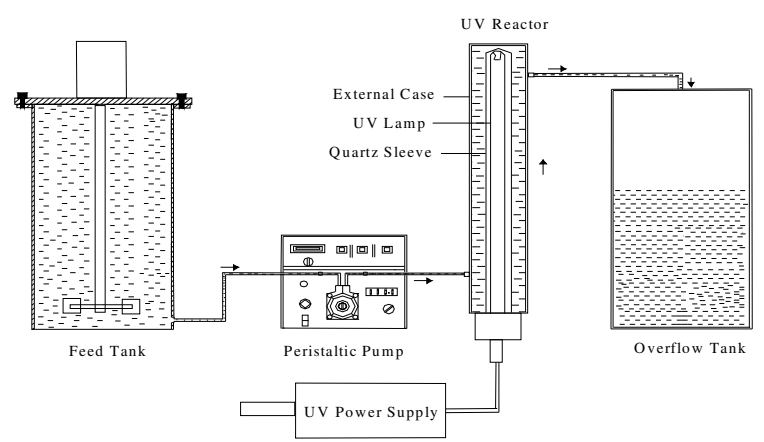

Fig. 1: Experimental setup
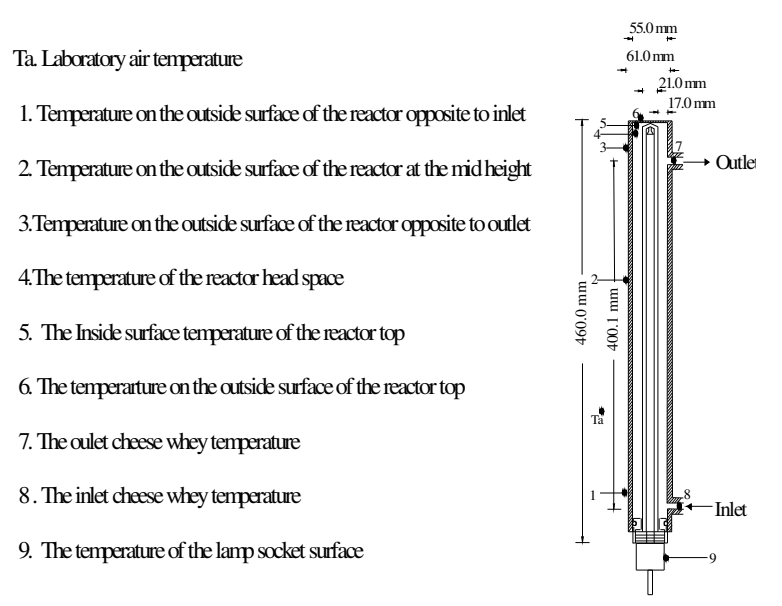

Fig. 2: Conventional UV reactor

UV Reactor: Two UV reactors arrangements were used: single conventional reactor and two conventional reactors in series. Figure 2 shows the geometry of a conventional UV reactor. A $380-\mathrm{mm}$ arc length low pressure mercury lamp enclosed in a 21-mm diameter (OD) quartz tube was used in the reactor. The inner and the outer diameter of the reactors were 55 and $61 \mathrm{~mm}$. The $3 \mathrm{~mm}$ thick stainless steel chamber gave a gap size (distance between the quartz sleeve and the inner surface of reactor casing) of $17 \mathrm{~mm}$ in the reactor.

Whey feeding and effluent removal system: The feeding and effluent removal system consisted of cheese whey feeding tank, a feeding pump and an effluent collection tank. The feeding tank (11L) was made of a Plexiglas cylinder of $4 \mathrm{~mm}$ wall thickness, $200 \mathrm{~mm}$ ID and $435 \mathrm{~mm}$ height. The bottom and cover of the tank were made of $4 \mathrm{~mm}$ thick Plexiglas circular plates. A mixing unit was used to ensure homogenous supply of cheese whey into the reactor. It consisted of stirring paddles (1.5 mm thick and $72 \mathrm{~mm}$ in length) connected to a mixing shaft (made from $9 \mathrm{~mm}$ diameter stainless steel of a $370.5 \mathrm{~mm}$ length) that was driven by an electric motor (Model 5935932, Type NSI-10RS3, Bodine Electric Company, Chicago, IL) mounted on top of the feeding tank cover. Variable speed peristaltic pumps and Masterflex precision tubing (Digi-Staltic, Masterflex model 7253-60, head model 77200-50, tubing no.EL-06429-14, Barnant Company, Division of Cole Parmer Instrument.Co., Barrington, IL.) were used to pump the cheese whey from the feeding tank into the UV reactors. A $10 \mathrm{~L}$ overflow tank made of $4 \mathrm{~mm}$ thick Plexiglas cylinder of $200 \mathrm{~mm}$ ID and $390 \mathrm{~mm}$ height, with the cover and the bottom of $4 \mathrm{~mm}$ thick Plexiglas plates of $210 \mathrm{~mm}$ diameter, was used.

Data logger: Type $\mathrm{T}$ thermocouples (Model 8530-75, 24 gauge, PVC insulation, Cole Parmer instrument company, Chicago, IL) and a Digital datalogger (Model 4702-5 E, Cole Parmer, Chicago, IL) were used to measure the temperatures in the reactors at nine different locations as shown in Fig. 2: (a) the outside surface of the reactor opposite to inlet, (b) the outside surface of the reactor at the mid height, (c) the outside surface of the reactor opposite to outlet, (d) the reactor head space, (e) Inside surface of the reactor top, (f) the outside surface of the reactor top, (g) outlet, (h) inlet and (i) the lamp socket surface. The temperature sensors (Thermocouples type T) were calibrated using ice and boiling deionized distilled water baths. The thermocouples were immersed into the ice bath and connected to the data acquisition system individually in different channels. The thermocouple reading, as temperature in degree centigrade, was corrected to read zero ${ }^{0} \mathrm{C}$ (offset) and then into the boiling water to correct the upper limit. The accuracy of the thermocouples was found to be $\pm 0.4{ }^{\circ} \mathrm{C}$.

Cheese whey collection and preparation The cheese whey was collected from Farmer's Cooperative Dairy Plant in Truro, Nova Scotia in several $40 \mathrm{~kg}$ heavy duty bags and stored in the Biotechnology Laboratory at about $-25{ }^{\circ} \mathrm{C}$ until needed. When required for use, a few bags were removed from the freezer and kept at room temperature to thaw and to increase the microbial population. Some characteristics of the cheese whey are presented in Table 1.

Experimental Protocol: The performance of the single conventional reactor was evaluated at eleven flow rates $\left(5,10,15,20,25,30,35,40,50,60\right.$ and $\left.70 \mathrm{~mL} \min ^{-1}\right)$ which gave retention times of $168,84,56,42,33.6,28$, $24,21,16.8,14$ and $12 \mathrm{~min}$, respectively. 
Am. J. Biochem. \& Biotech., 2 (3): 89-96, 2006

Table 1: Some characteristics of the cheese whey used in the study

\begin{tabular}{|c|c|c|}
\hline Characteristics & Measured value & Units \\
\hline Total solids & 68300 & $\mathrm{mg} \mathrm{L}^{-1}$ \\
\hline Fixed solids & 6750 & $\mathrm{mg} \mathrm{L}^{-1}$ \\
\hline Percent fixed solids & 10 & $\%$ \\
\hline Volatile solids & 61550 & $\mathrm{mg} \mathrm{L}^{-1}$ \\
\hline Percent volatile solids & 90 & $\%$ \\
\hline Suspended solids & 25160 & $\mathrm{mg} \mathrm{L}^{-1}$ \\
\hline Fixed solids & 230 & $\mathrm{mg} \mathrm{L}^{-1}$ \\
\hline Percent fixed solids & 1 & $\%$ \\
\hline Volatile solids & 24930 & $\mathrm{mg} \mathrm{L}^{-1}$ \\
\hline Percent volatile solids & 99 & $\%$ \\
\hline Total Kjeldahl nitrogen & 1560 & $\mathrm{mg} \mathrm{L}^{-1}$ \\
\hline Ammonium nitrogen & 260 & $\mathrm{mg} \mathrm{L}^{-1}$ \\
\hline Percent ammonium nitrogen & 17 & $\%$ \\
\hline Organic nitrogen & 1300 & $\mathrm{mg} \mathrm{L}^{-1}$ \\
\hline Percent organic nitrogen & 83 & $\%$ \\
\hline Total chemical oxygen demand & 81050 & $\mathrm{mg} \mathrm{L}^{-1}$ \\
\hline Soluble chemical oxygen demand & 68050 & $\mathrm{mg} \mathrm{L}^{-1}$ \\
\hline Percent soluble chemical oxygen demand & 85 & $\%$ \\
\hline Insoluble chemical oxygen demand & 13000 & $\mathrm{mg} \mathrm{L}^{-1}$ \\
\hline Percent insoluble chemical oxygen demand & 15 & $\%$ \\
\hline Biological oxygen demand $\left(\mathrm{BOD}_{5}\right)$ & 52220 & $\mathrm{mg} \mathrm{L}^{-1}$ \\
\hline Lactose & 50000 & $\mathrm{mg} \mathrm{L}^{-1}$ \\
\hline Fat & 4700 & $\mathrm{mg} \mathrm{L}^{-1}$ \\
\hline Protein & 9953 & $\mathrm{mg} \mathrm{L}^{-1}$ \\
\hline \multicolumn{3}{|l|}{ Elements } \\
\hline Magnesium & 94 & $\mathrm{mg} \mathrm{L}^{-1}$ \\
\hline Calcium & 429 & $\mathrm{mg} \mathrm{L}^{-1}$ \\
\hline Manganese & 1 & $\mathrm{mg} \mathrm{L}^{-1}$ \\
\hline Potassium & 1670 & $\mathrm{mg} \mathrm{L}^{-1}$ \\
\hline Sodium & 684 & $\mathrm{mg} \mathrm{L}^{-1}$ \\
\hline Iron & 42 & $\mathrm{mg} \mathrm{L}^{-1}$ \\
\hline Phosphorus & 154 & $\mathrm{mg} \mathrm{L}^{-1}$ \\
\hline Sulfur & 483 & $\mathrm{mg} \mathrm{L}^{-1}$ \\
\hline Others & 3193 & $\mathrm{mgL}^{-1}$ \\
\hline Cell number & $7.6 \times 10^{6}$ & cellsmL ${ }^{-1}$ \\
\hline $\mathrm{pH}$ & 5.00 & \\
\hline
\end{tabular}

The performance of the conventional reactor series was evaluated at five flow rates $(35,40,50,60$ and $70 \mathrm{~mL}$ $\min ^{-1}$ ), which gave retention time of 48, 42, 33.6, 28 and $24 \mathrm{~min}$, respectively.

Before starting the experiments, the UV reactors and all accessories (feeding tank, overflow tank, tubing's) were cleaned with detergent and hot water and then chemically sterilized using $2 \%$ sodium metabisulfite solution to eliminate any microbial contamination. The UV reactors and all accessories were then washed with hot water several times in order to eliminate any chemical traces. The UV reactors were operated empty for $15 \mathrm{~min}$ (with UV) to eliminate any possible contamination. The cheese whey was pumped through the reactors at the required flow rates using the peristaltic pumps while the UV lamp is on. After the reactor was filled with cheese whey, it was left to reach steady state (constant temperature). The temperature readings were noted down from the data logger. The accumulated power input consumption was measured using power meter (True RMS Power Multimeter, Model 382860, ExTech Instrument Waltham, MA).

Samples were collected during the steady state from the effluent for the plate count analysis. To evaluate the extent of fouling, the UV lamps were observed visually at the end of each experiment. The conventional reactor series was operated continuously for $12 \mathrm{hrs}$ at the flow rates of $35 \mathrm{~mL} \mathrm{~min}^{-1}$ (which gave retention time $48 \mathrm{~min}$ ) in order to determine the effective operational time.

Microbial Analysis: Untreated and UV treated cheese whey samples were analyzed for their microbial counts. A plate count agar (DIFCO, 0751-17-2), which contained $5 \mathrm{~g}$ of bacto yeast agar all dissolved in $1 \mathrm{~L}$ was prepared, sterilized at $121{ }^{\circ} \mathrm{C}$ and $101.4 \mathrm{kPa}$ for 15 min in an autoclave (model STM-E, Market Forge Sterilmatic, New York, NY) and then poured into several Petri dishes. Serial dilutions of $10^{-1}$ to $10^{-7}$ were prepared from the samples. An aliquot of $0.1 \mathrm{ml}$ of each of the dilutions was placed on the plate count agar in the Petri dish (in triplicate) and gently swirled until consistently spread on the agar surface with the glass spreader. The Petri dishes were incubated at $32{ }^{\circ} \mathrm{C}$ in an incubator (Fisher Isotemp ${ }^{*}$, Cat. No. 11-680-626, Fisher Scientific, Whitby, Ontario) until visible growth was observed. The samples were collected from the outlet immediately after the treatment. The visible growth of colonies was counted as colony forming units per millimeter (CFU $\left.\mathrm{mL}^{-1}\right)$ according to the procedure described in the Standard Methods for the Examination of Dairy Products ${ }^{[23]}$.

\section{RESULTS AND DISCUSSION}

Microbial survival: Cheese whey with an initial mixed microbial population of $7.6 \times 10^{6}$ cells $\mathrm{mL}^{-1}$ was used in the study. The final microbial populations in the effluents of the single UV reactor and the two reactor series are shown in the Table 2. The results are the average of the three replicates. The coefficient of variation varied from 0.0 to $9.3 \%$.

Survival curves are commonly used to interpret the destruction kinetics of microorganism. They are semi $\log$ plots of the ratio of the concentrations of the final number of organisms found after UV treatment $(\mathrm{N})$ to the initial number of microorganisms $\left(\mathrm{N}_{\mathrm{o}}\right)$ versus residence time (flow rate) as shown in Fig. 3. The results obtained from the single conventional reactor and two conventional reactor series showedthat the UV radiations are capable of reducing the microbial population in the cheese whey. The value of $\mathrm{N} / \mathrm{N}_{\mathrm{o}}$ increased from 0.006 to 0.684 in the single reactors and from 0.000 to 0.38 in the series reactor as the residence time increased from 5 to $70 \mathrm{~mL} \mathrm{~min} \mathrm{mi}^{-1}$ and from 35 to $70 \mathrm{~mL} \mathrm{~min}^{-1}$, respectively. Longer residence times increased the possibility of the scattered UV radiation hitting the microbial cells and causing germicidal effect. Darby et al. ${ }^{[11]}$ stated that as with chemical disinfection, the liquid medium must have sufficient contact time with the UV light.

The relationship between the survival ratio $\left(\mathrm{N} / \mathrm{N}_{\mathrm{o}}\right)$ and the residence time (t) in the single conventional reactor and the conventional reactor series can be described by the following exponential equation: 
$\mathrm{N} / \mathrm{N}_{0}=\mathrm{e}^{-\mathrm{kt}}$

Where:

$\mathrm{k} \quad$ is the destruction rate constant $\left(\mathrm{min}^{-1}\right)$

$\mathrm{t}$ is the residence time ( $\mathrm{min}$ )

Figure 4 shows a graphical determination of the destruction rate $(\mathrm{k})$ and the time required to kill the entire population $\left(\mathrm{t}_{\mathrm{cr}}\right)$. The destruction rate was 0.07 and $0.17 \mathrm{~min}^{-1}$ for the single reactor and the two reactor series, respectively. From the results, it would require at least $405 \mathrm{~min}$ in the single conventional reactor and 48 min in the conventional reactor series to destroy the whole initial microbial population in the cheese whey.

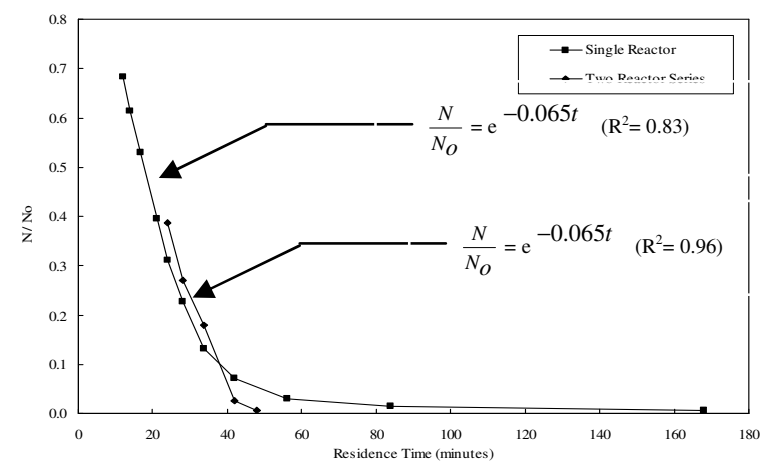

a. Residence time

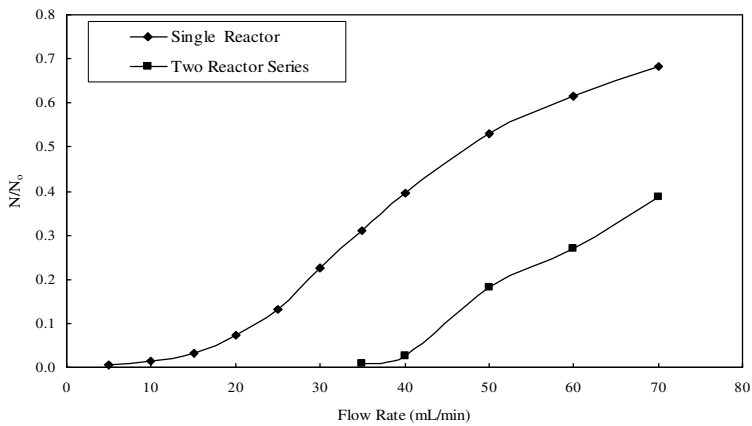

b. Flow rate

Fig. 3: Survival curves

Destruction efficiency: The effect of the flow rate (residence time) on the destruction efficiency is shown in Fig. 5.

The destruction efficiency of the single reactor decreased from $99.4 \%$ to $31.6 \%$ as the flow rate increased from 5 to $70 \mathrm{~mL} \mathrm{~min}^{-1}$ (from 168 to $12 \mathrm{~min}$ residence time). When two conventional reactors were used in series, the destruction efficiency reached $100 \%$ at the flow rate of $35 \mathrm{~mL} \mathrm{~min}^{-1}$ (48 min retention time) and then decreased with increases in the flow rate reaching $61.25 \%$ at the flow rate of $70 \mathrm{~mL} \mathrm{~min}^{-1}(24$ min retention time). Beltran and Canovas ${ }^{[22]}$ while conducting a study on inactivation of Saccharomyces cerevisiae, Escherichia coli and Listeria innocua in apple juice by ultraviolet light suggested the use of more than one reactor to increase the disinfection effectiveness. McDonald et al. ${ }^{[25]}$ stated that liquid in the UV reactor must have sufficient residence time and

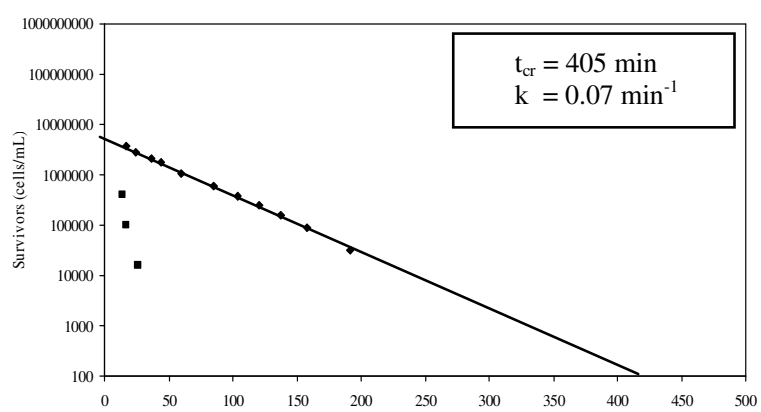

a. Single reactor

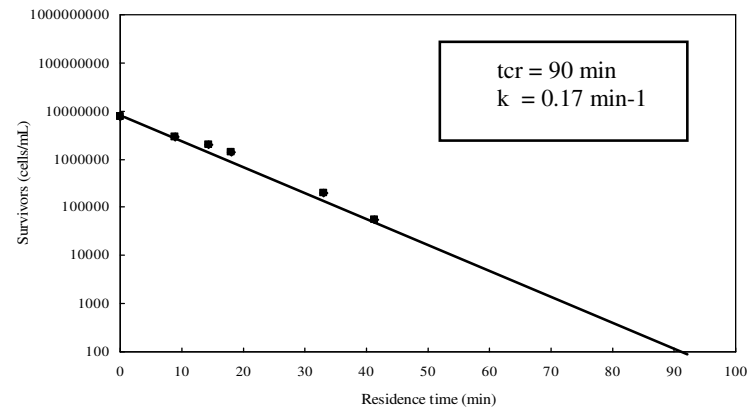

b. Two reactor series

Fig. 4: Graphical determination of the destruction rate and the time required to destroy the entire population

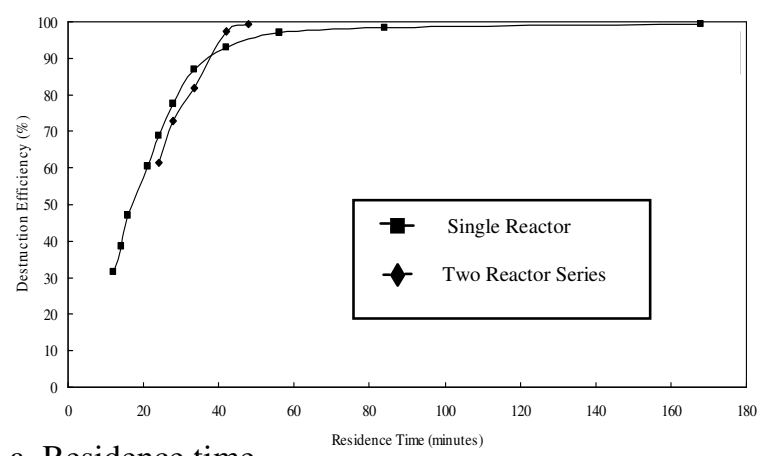

a. Residence time

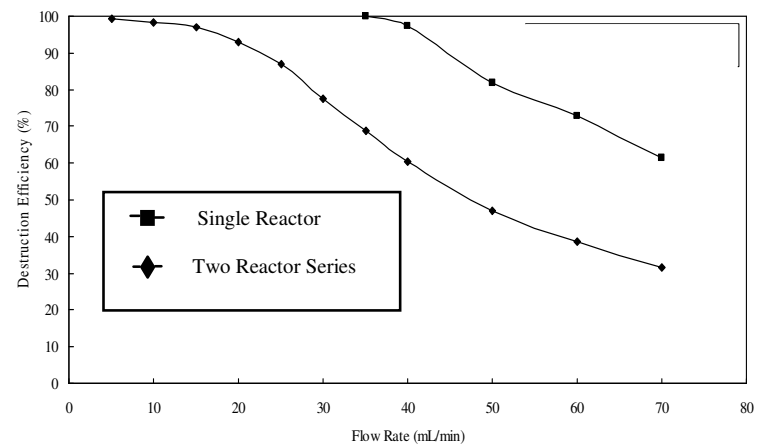

b. Flow rate

Fig. 5: The destruction efficiencies at different residence times (flow rates)

turbulent mixing to achieve dose equilibrium. While sterilizing cheese whey using UV reactors, Mahmoud and Ghaly ${ }^{[17]}$ found that the cell removal efficiency 
Am. J. Biochem. \& Biotech., 2 (3): 89-96, 2006

Table 2: $\quad$ Effect of flow rate on final cell number and destruction efficiencies

\begin{tabular}{|c|c|c|c|c|c|c|}
\hline \multirow[t]{3}{*}{ Flow Rate (mL/min) } & \multicolumn{2}{|c|}{ Residence Time (min) } & \multicolumn{2}{|c|}{ Cell Number (cells/mL) } & \multicolumn{2}{|c|}{ Destruction Efficiency (\%) } \\
\hline & Single & Reactor & Single & Reactor & Single & Reactor \\
\hline & Reactor & Series & Reactor & Series & Reactor & Series \\
\hline 5 & 168.0 & & 0.046 & & 99.40 & \\
\hline 10 & 84.0 & & 0.122 & & 98.40 & \\
\hline 15 & 56.0 & & 0.236 & & 96.90 & \\
\hline 20 & 42.0 & & 0.547 & & 92.80 & \\
\hline 25 & 33.6 & & 1.003 & & 86.80 & \\
\hline 30 & 28.0 & & 1.718 & & 77.40 & \\
\hline 35 & 24.0 & 48.0 & 2.364 & 0.000 & 68.90 & 100.00 \\
\hline 40 & 21.0 & 42.0 & 3.010 & 0.197 & 60.40 & 97.40 \\
\hline 50 & 16.8 & 33.6 & 4.028 & 1.372 & 47.00 & 81.95 \\
\hline 60 & 14.0 & 28.0 & 4.669 & 2.059 & 38.56 & 72.90 \\
\hline 70 & 12.0 & 24.0 & 5.200 & 2.945 & 31.58 & 61.25 \\
\hline
\end{tabular}

Initial cell number is $7.6 \times 10^{6}($ cells $/ \mathrm{mL})$

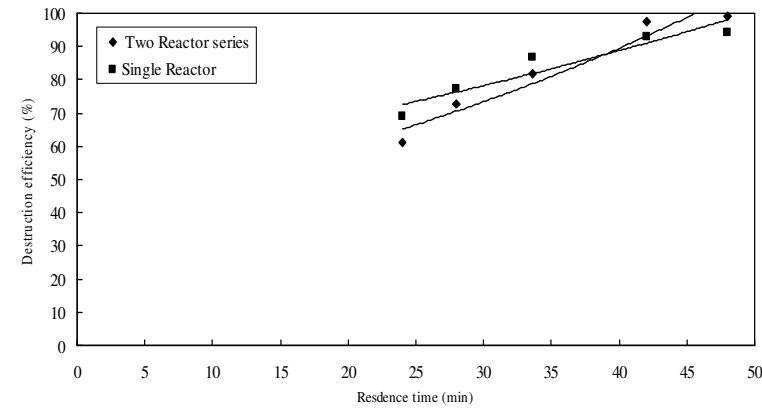

a. Residence time

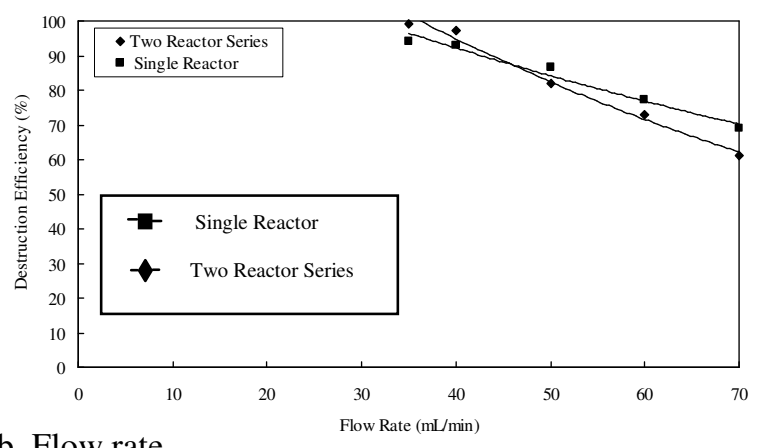

b. Flow rate

Fig. 6: Comparison of destruction efficiency of the single and series reactors at the same flow rates (residence times)

increased with increase in residence time (decrease in flow rate). In this study, using two conventional reactors in series doubled the residence time and thus achieved higher destruction efficiencies.

The destruction efficiency obtained in this study was similar to those reported by several authors. Rajala et al. ${ }^{[26]}$ reported a disinfection efficiency of $99.9 \%$ in the pilot UV reactor used for wastewater treatment. Wright et al. ${ }^{[27]}$, while using a thin film ultraviolet reactor to treat inoculated unpasteurized apple cider (a mixture of five strains of Escherichia coli O157: H7) reported a disinfection efficiency of $99.98 \%$. Harrington and Hills ${ }^{[28]}$ obtained a disinfection efficiency of $99.78 \%$ in fresh apple cider. Beltran and

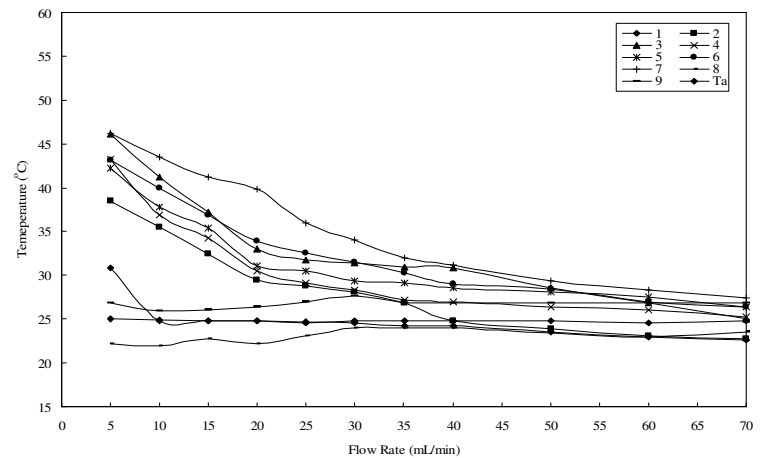

a. Single reactor

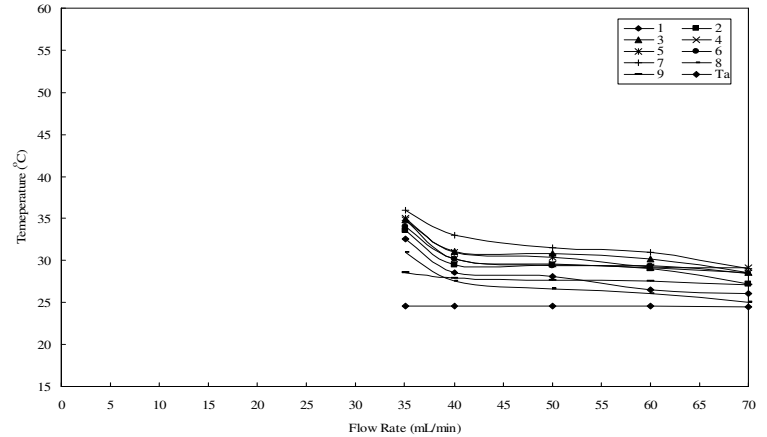

b. Two reactor series

Fig. 7: Effect of flow rate on the steady state temperatures

Canovas $^{[22]}$ reported a disinfection efficiency of 89.78 97.97\% for S.cerevisiae, $98.87-99.99 \%$ for L.Innocua and $99.9899 .99 \%$ for E.coli while using UV reactor for treating apple juice.

The results showed that the destruction efficiencies of the single reactor and the two reactors series at similar residence time (flow rates) are comparable (Fig. 6). However, using two reactors in series allowed for high flow rates and thus increased the throughout of the sterilization process. The maximum effective flow rate at which $100 \%$ destruction efficiency can be achieved was 2.07 and $35.00 \mathrm{~mL} \mathrm{~min}^{-1}$ for the single reactor and the two reactor series, respectively. 
Am. J. Biochem. \& Biotech., 2 (3): 89-96, 2006

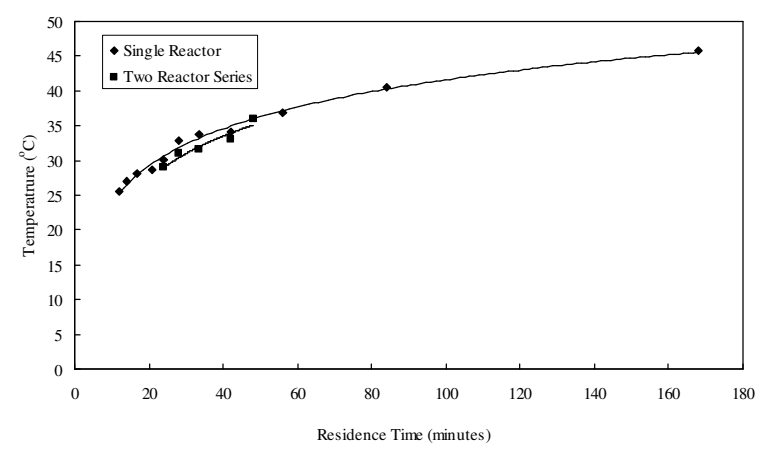

a. Residence time

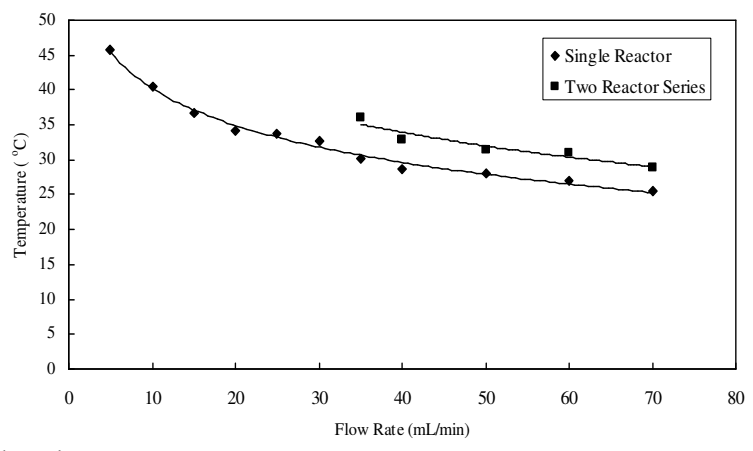

b. Flow rate

Fig. 8: Effect of residence time (flow rate) on the steady state outlet temperatures

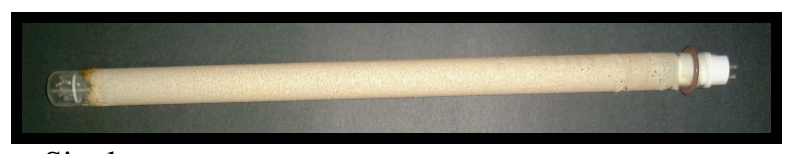

a. Single reactor

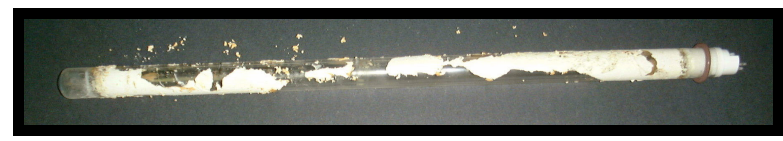

b. Two reactor series

Fig. 9: Photograph showing fouling on UV lamps

Flow characteristics: Generally, the flow is laminar when the Reynolds number is less than 4000 and is turbulent when it is greater than $4000^{[29]}$. Reynolds numbers were calculated using following equations:

$\operatorname{Re}=U d_{h} / v$

$\mathrm{d}_{\mathrm{h}}=\mathrm{D}_{\mathrm{o}}-\mathrm{D}_{\mathrm{i}}$

$U=\mathrm{q} / \mathrm{A}_{\mathrm{c}}$

$\mathrm{A}_{\mathrm{c}}=\pi\left(\mathrm{D}_{\mathrm{o}}{ }^{2}-\mathrm{D}_{\mathrm{i}}{ }^{2}\right)$

Where:

$A_{c}$ is the annular section area $\left(\mathrm{m}^{2}\right)$

$\mathrm{d}_{\mathrm{h}}$ is the hydraulic diameter $(\mathrm{m})$

$D_{i}$ is the inner diameter $(m)$

$D_{0}$ is the outer diameter $(m)$

$\mathrm{q}$ is the volumetric flow rate $\left(\mathrm{m}^{3} \mathrm{~s}^{-1}\right)$

$U$ is the mean velocity $\left(\mathrm{m} \mathrm{s}^{-1}\right)$

$\mathrm{N}$ is the fluid kinematic viscosity $\left(\mathrm{m}^{2} \mathrm{~s}^{-1}\right)$

The results showed that the flow was laminar in both the reactors at all flow rates $\left(\mathrm{R}_{\mathrm{e}}=1.39-20.10\right.$ for flow rates of 5-70 $\mathrm{mL} \mathrm{min}^{-1}$ ).
Table 3: Composition of fouling materials obtained from the UV reactor $(\mathrm{mg} / \mathrm{kg})$

\begin{tabular}{lccr}
\hline Constituent & Cheese Whey $(\mathrm{mg} / \mathrm{kg})$ & $\begin{array}{c}\text { Fouling Material } \\
\text { Concentration } \\
(\mathrm{mg} / \mathrm{kg})\end{array}$ & $\begin{array}{c}\text { Increase } \\
(\%)\end{array}$ \\
\hline Protein & & 108600 & 91.1 \\
Fat & 9953 & 21500.0 & 57.0 \\
Minerals & 4700 & 179.0 & 90.4 \\
Magnesium & & 586.0 & 36.5 \\
Calcium & 94 & 4.0 & 300.0 \\
Manganese & 1 & 3300.0 & 97.6 \\
Potassium & 1670 & 1070.0 & 56.4 \\
Sodium & 684 & 130.0 & 209.0 \\
Iron & 42 & 2290.0 & 1387.0 \\
Phosphorous & 154 & 2500.0 & 417.0 \\
Sulfur & 483 & & \\
\hline
\end{tabular}

Singh and Ghaly ${ }^{[18]}$ suggested the use of coil reactors in order to provide mixing and hence increase the destruction efficiency while maintaining low residence time. Koutchma et $a l^{[30]}$ used turbulent flow UV reactors and found that higher flow rates resulted in increased disinfection efficiencies. Forney and Pierson ${ }^{[21]}$ suggested the use of two concentric cylinders to provide efficient exposure of microbes to UV light and hence increase the destruction efficiency.

Temperature: Figure 7 shows the variations of steady state temperatures (at 9 locations) with the changes of the flow rate in the reactors. The results indicated that there were increases in the temperature at all locations in the reactors (except the inlet temperature) until the reactors were filled up. At the steady state, the temperatures at all locations in the reactors decreased with the increase in flow rate. The temperatures measured close to the bottom of the reactors were less than the temperatures measured at the top because the liquid (which was kept at room temperature) entered the reactor at the bottom and picked up heat from the lamp as it traveled upward to the outlet. The relationships between the outlet temperature and flow rate are shown in Fig. 8. The steady state effluent temperature decreased from $45.8{ }^{\circ} \mathrm{C}$ at $5 \mathrm{~mL} \mathrm{~min}{ }^{-1}$ to $25.5{ }^{\circ} \mathrm{C}$ at $70 \mathrm{~mL} \mathrm{~min}^{-1}$ in the single conventional reactor and from $36{ }^{\circ} \mathrm{C}$ at $35 \mathrm{~mL} \mathrm{~min}^{-1}$ to $29{ }^{\circ} \mathrm{C}$ at $70 \mathrm{~mL} \mathrm{~min}{ }^{-1}$ in the conventional reactor series.

The outlet temperature reported in the literature for various UV reactors varied from $10{ }^{\circ} \mathrm{C}$ to $62.8{ }^{\circ} \mathrm{C}^{[17,30-}$ ${ }^{32]}$. According to environmental technology verification program conducted by $\mathrm{EPA}^{[33]}$ on UV reactors produced by Trojan Technologies Incorporated (Canada), the temperature of the effluent will vary depending on the flow rate and the reactor geometry.

Fouling: Fouling of a UV lamp is a process of progressive decline in efficiency with time, due to accumulation of deposits onto a heat transfer surface through which heat and/or radiations are transferred. Suspended particles and high turbidity of the liquid medium have been found to reduce the penetration ability of the UV light and thus reduce the efficiency of 
the UV conventional reactor ${ }^{[17]}$. Fouling will block (and/or absorb) UV light from penetrating the treated effluent and will potentially reduce the disinfection capabilities of the UV reactor.

Visual observation of the UV lamps in the single reactor revealed more fouling compared to two reactor series (Fig. 9). 100\% destruction efficiency was achieved in the conventional reactor series at the flow rates of $35 \mathrm{~mL} \mathrm{~min}^{-1}$ for $25 \mathrm{~min}$ and then decreased with time, reaching $29.89 \%$ after 6 hrs and $0.00 \%$ after $12 \mathrm{hrs.} 100 \%$ destruction efficiency was never achieved in the single reactor.

Lin et al. ${ }^{[34]}$ investigated the chemistry and characterizations of the inorganic materials that foul quartz surfaces in UV system used for disinfecting water. Their study showed that essentially all metals that could be measured in waters being subjected to irradiation were present in fouling materials. Cation composition in the fouling materials was found to be highly complex, with many metals being common to all samples with iron, aluminum and calcium represent the majority of metals present. Predominant anions included: carbonate, sulfate, hydroxide, chloride and phosphate. Cairns ${ }^{[35]}$ proposed fouling to be a net process of loading and removal of UV absorbing organics and/or organics present in the liquid medium and suggested adsorption as one mechanism of fouling.

The fouling material found in thus study was a rubber like material completely surrounding the quartz tube. It was morphologically homogeneous and consistent along the whole lamp. Chemical analyses performed on this fouled material revealed the presence of fats, proteins and minerals $(\mathrm{Mg}, \mathrm{Ca}, \mathrm{Mn}, \mathrm{K}, \mathrm{Na}, \mathrm{Fe}$, $\mathrm{P}$ and $\mathrm{S}$ ) as shown in Table 3. Mahmoud and Ghaly ${ }^{[17]}$ found similar material and concluded that lamp fouling was due to increases in the cheese whey temperature.

Although the two reactors in series had less fouling and achieved 100\% destruction efficiency, $25 \mathrm{~min}$ effective operational time is very short. A different design in which there is no contact between the liquid and the UV lamp should be investigated. The quartz sleeve could also be replaced with fluropolymer coiled tube around the UV lamp. The smooth surface of the fluropolymer would reduce scaling and extend the effective operating time.

\section{CONCLUSION}

Hundred percent $100 \%$ destruction efficiency could not be achieved in the single conventional reactor. The destruction efficiency in the single reactor decreased from $99.40 \%$ at the flow rate of $5 \mathrm{~mL} \mathrm{~min}^{-1}$ to $31.6 \%$ at the flow rate of $70 \mathrm{~mL} \mathrm{~min}^{-1}$. When two conventional reactors were connected in series, the destruction efficiency decreased from $100.00 \%$ at the flow rate of $35 \mathrm{~mL} \mathrm{~min}^{-1}$ to $61.25 \%$ at the flow rate of $70 \mathrm{~mL} \mathrm{~min}^{-1}$. $100 \%$ destruction efficiency was achieved at the flow rate of $35 \mathrm{~mL} \mathrm{~min}^{-1}$ in the two reactor series and lasted for $25 \mathrm{~min}$. The rate of microbial destruction was found to be exponential in the single reactor and the two reactor series. The flow was laminar in all reactors, the Reynolds number varied from 1.39 (at $5 \mathrm{~mL} \mathrm{~min}^{-1}$ ) to 20.10 (at $70 \mathrm{~mL} \mathrm{~min}^{-1}$ ). The maximum effluent temperatures in the single reactor and the two reactor series were 45.8 and $36{ }^{\circ} \mathrm{C}$, respectively. Fouling was found to be a major limitation. A different design in which there is no contact between the liquid and the UV lamp should be investigated. The quartz sleeve could also be replaced with fluropolymer coiled tube around the UV lamp. The smooth surface of the fluropolymer would reduce scaling and extend the effective operating time.

\section{ACKNOWLEDGEMENTS}

This research was funded by the National Science and Engineering Council of Canada (NSERC).

\section{REFERENCES}

1. Zall, R.R, 1992. Sources and Composition of Whey and Permeate. In: Whey and Lactose Processing, Zadow, J. G. (Ed.), Elsevier Science Pub. Co., New York, NY.

2. Yang, S.T., H. Zhu, Y. Li and E.M. Silva, 1993. A novel multi-phase bioreactor for fermentations to produce organic acids from dairy wastes. Proc. First Biomass Conf. Americas, Burlington, Vermont, 2: 1223-1248.

3. Ghaly, A.E. and M.S.A. Tango, 2000. Continuous lactic acid production using Lactobacillus helveticus in packed bed immobolized cell system. Proc. XIV Memorial CIGR World Congress 2000, Tsukuba, Japan.

4. FAO, 2002. FAO year book. Food and Agricultural Organization of the United Nations, 56, Rome, Italy.

5. Yang, S.T., I.C. Tang and H. Zhu, 1992. A novel fermentation process for calcium magnesium acetate (CMA) production from cheese whey. Appl. Biochem. Biotechnol., 34-35: 569-583.

6. Siso, M.I.G, 1996. The biotechnological utilization of cheese whey: review. Biores. Technol., 57: 1-11.

7. Hall, E.R. and G.P. Adams, 1988. Anaerobic Treatment of Cheese Whey. In: What's New in Wastewater Technology? Environment Canada, Ottawa, ON.

8. Ghaly, A.E., R.K. Singh and J.R. Burney, 1985. Land disposal of cheese whey. CSAE.Paper NO.85-301, Charlottetown, Prince Edward Island, Canada.

9. Ghaly, A.E. and A.A. El-Taweel, 1995. Effect of lactose concentration on batch production of ethanol from cheese whey using Candida Pseudotropicalis. Trans. ASAE, 38: 1113-1120. 
10. Sandhu, D.K. and M.K. Waraich, 1983. Conversion of cheese whey to single cell protein. Biotechnol. Bioengg., 25: 797-808.

11. Ghaly, A.E., R.M. Ben-Hassan and N. BenAbdallah, 1992. Utilization of cheese whey lactose by $K$. fragilis for growth and energy under continuous fermentation. Appl. Biochem. Biotechnol., 36: 301-322.

12. Balasubramanian, N., J.S. Kim and Y.Y. Lee, 2001. Fermentation of xylose into acetic acid by Clostridium thermoaceticum. Appl. Biochem. Biotechnol., 91-93: 367-376.

13. Ghaly, A.E., M.S.A. Tango, N.S. Mahmoud and A.C. Avery, 2004. Batch propagation of Lactobacillus helveticus with microaeration for production of lactic acid from nutrient supplement whey with high lactose concentration. World J. Microbiol. Biotechnol., 20: 65-75.

14. Fitzpatrick, J.J., M. Ahrens and S. Smith, 2001. Effect of manganese on Lactobacillus casei fermentation to produce lactic acid from whey permeate. Process Biochem., 36: 671-675.

15. Talabaradon, M., J.P. Schwitzguebel and P. Peringer, 2000. Anaerobic thermophilic fermentation for acetic acid production from milk permeate. J. Biotechnol., 76: 83-92.

16. Ghaly, A.E., A.Al Taweel, H. Gomaa, M. Tango, J.B. Pyke and C. Cooney, 2001. Production of antiicing/de-icing agents from cheese whey. Proceedings of 11th World Conference of Food Science and Technology, Soul, Korea.

17. Mahmoud, N.S. and A.E. Ghaly, 2004. On-line sterilization of cheese whey using ultraviolet radiations. Biotechnol. Progr., 20: 550-560.

18. Singh, J.P. and A.E. Ghaly, 2006. Effect of flow characteristics on online sterilization of cheese whey in UV reactors. Biochem. Appl. Biotechnol. In Press.

19. Lund, D., E. Plett and C. Sandhu, 1985. Fouling and cleaning in food processing. University of Wisconsin-Madison Extension Duplicating, Madison, Wisconsin 53706, USA.

20. Epstein, N, 1983. Fouling of Heat Exchangers. In Heat Exchangers Theory and Practice. McGraw Hill Inc, NY.

21. Forney, L.J. and J.A. Pierson, 2004. Improved methods of UV processing for fruit juices. Resource, 11: 7 .

22. Beltran, J.A.G. and G.V.B. Canovas, 2005. Reduction of Saccharomyces cerevisiae, Escherichia coli and Listeris innocua in apple juice by ultraviolet light. J. Food Proc. Engg., 28: 437-452.

23. APHA, 1967. Standard Methods for the Examination of Dairy Products. American Public Health Association, Washignton, D.C.
24. Darby, J.L., K.E. Snider and G. Tchobanoglous, 1993. Ultraviolet disinfection for wastewater reclamation and reuse subject to restrictive standards. Water Environ. Res., 65: 169-180.

25. McDonald, K., T. Clevenger, R. Curry and G. Jeffery, 2000. Ultraviolet light technolgies for water treatment. In Environmental and Pipeline Engineering, ASCE: Reston, VA: 299-311.

26. Rajala, R.L., M. Pulkkamen, M. Pessi and T.H. Heinomen, 2003. Removal of microbes from municipal wastewater effluent by rapid sand filtration and subsequent UV irradiation. Water Sci. Technol., 47: 157-162.

27. Wright, J.R., S.S. Sumner, C.R. Hackney, M.D. Pierson and B.W. Zoecklein, 2000. Efficacy of ultraviolet light for reducing Escherichia coli O157:H7 in unpasteurized cider. Food Prot., 63: 563-567.

28. Harrington, W.O. and C.H. Hills, 1968. Reduction of the microbial population of apple cider by ultraviolet irradiation. Food Technol., 22: 117-120.

29. Cengel, Y.A, 2003. Heat Transfer: A Practical Approach. Sec. Edn., McGraw-Hill, Boston, MA.

30. Koutchma, T., S.K. Stuart, C. Stuary, B. Parisi, 2004. Ultraviolet disinfection of juice products in laminar and turbulent flow reactors. Innovative Food Sci. and Emerging Technol., 5: 179-189.

31. Tran, M. T. T. and M. Farid, 2004. Ultraviolet treatment of orange juice. Innovative Food Science and Emerging Technologies, 5 (4): 495-502.

32. Abu-ghararah, Z. H, 1994. Effect of temperature on the kinetics of wastewater disinfection using ultraviolet radiation. J. Environ. Sci. Health, A29: 585-603.

33. USEPA, 2002. The environmental technology verification program. Trojan Technologies Incorporated. [online] http://www.epa.gov/etv/pdfs/vrvs/02vstrojan.pdf.

34. Lin, L., C.T. Johnston and E.R. Blatchey III, 1999. Inorganic fouling at quartz: water interfaces in ultraviolet photo reactors - II - Temporal and Spatial distributions. Water Res., 33: 3330- 3338.

35. Cairns, W.L., 1996. Comparison of UV disinfection technologies using low intensity monochromatic and high intensity polychromatic UV lamps. Proc., Disinfecting Wastewater for Discharge and Reuse, Water Environment Federation, Portland, OR, 10-47: 10-52. 